"Przegląd Prawa Konstytucyjnego" Nr $3(15) / 2013$

\title{
Sprawozdanie
}

\section{Konferencja naukowa: Senat w tradycji i praktyce ustrojowej Rzeczypospolitej, Senat, Warszawa 11 grudnia 2012 r.}

Dnia 11 grudnia 2012 r. w sali posiedzeń Senatu RP odbyła się konferencja naukowa pt. Senat $w$ tradycji i praktyce ustrojowej Rzeczypospolitej, która została zorganizowana w ramach obchodów 90. rocznicy pierwszego posiedzenia Senatu II Rzeczpospolitej. Natomiast 28 listopada 2012 r. odbyło się uroczyste posiedzenie Senatu, w którym udział wzięli m.in. prezydent RP Bronisław Komorowski, marszałek Sejmu Ewa Kopacz, premier Donald Tusk, marszałek Senatu V kadencji Longin Pastusiak, wicemarszałek Senatu I kadencji Andrzej Wielowieyski, wicemarszałek Senatu II kadencji Andrzej Czapski, prof. Jerzy Buzek, reprezentujący rodziny senatorów II RP. Konferencję naukową zorganizowała Kancelaria Senatu we współpracy z Polskim Towarzystwem Historycznym oraz Polskim Towarzystwem Nauk Politycznych.

Konferencję otworzył punktualnie o godzinie 11 marszałek Senatu Bogdan Borusewicz. Program konferencji był podzielony na dwa panele tematyczne - historyczny oraz politologiczny. Pierwszy z nich skupiał się wokół genezy Senatu I Rzeczypospolitej oraz zagadnień Senatu II Rzeczypospolitej. Poprowadził go prof. dr hab. Tomasz Schramm z Uniwersytetu Adama Mickiewicza w Poznaniu. Podczas trwania pierwszego z paneli swe referaty wygłosiło trzech prelegentów. Profesor dr hab. Krzysztof Mikulski (UMK) w bardzo interesujący sposób przedstawił genezę, skład oraz kompetencje Senatu I Rzeczpospolitej, sięgając w swym wystąpieniu jeszcze do czasów poprzedniczki Senatu, którą była Rada Królewska. Zaraz po nim wystąpił prof. dr hab. Włodzimierz Mędzrzecki (UW), który mówił o Senacie II Rzeczpospolitej na tle innych izb wyższych $w$ parlamentach europejskich. W swo- 
im wystąpieniu wspomniał również o restytucji instytucji Senatu w okresie międzywojennym oraz jego roli. Ostatnim prelegentem w panelu historycznym był prof. dr hab. Czesław Osękowski (UZ), który mówił o Referendum Ludowym z 30.06.1946 i zniesienia Senatu przez władze ludowe. W swoim wystąpieniu otwarcie mówił o sfałszowaniu wyniku referendum przez władze komunistyczne oraz o jego skutkach. Następnie rozgorzała się gorąca dyskusja, po której wszyscy zaproszeni goście udali się na przerwę.

Drugi panel, politologiczny, poprowadził prof. dr hab. Roman Bäcker z Uniwersytetu Mikołaja Kopernika w Toruniu. Wystąpiło w nim dwóch prelegentów: prof. dr hab. Ryszard Chruściak oraz prof. dr hab. Jarosław Szymanek, obaj przedstawiciele Uniwersytetu Warszawskiego. Profesor Chruściak mówił o Senacie w systemie politycznym III Rzeczypospolitej, natomiast drugi z prelegentów poruszył zagadnienie Drugiej izby $w$ systemach politycznych państw współczesnych. Jednym z ostatnich etapów Konferencji była dyskusja wokół panelu politologicznego oraz poprzedzający ją panel dyskusyjny. Kilka minut po godzinie 14 rozpoczął się wcześniej już wspomniany panel dyskusyjny na temat: „Senat III Rzeczypospolitej w dyskursie politycznym oraz naukowym”, pomiędzy: prof. dr hab. Ryszardem Chruściakiem (UW), prof. dr hab. Krzysztofem Skotnickim (UŁ), prof. dr hab. Jarosławem Szymankiem (UW), dr Joanną Marszałek-Kawą (UMK) oraz dr Ryszardem Piotrowskim (UW). Na uwagę zasługuje wypowiedź prof. Skotnickiego, który stwierdził, iż rolę Senatu można wzmocnić np. poprzez różne terminy wyborów do Sejmu i Senatu, idąc wzorem czeskiego parlamentu, co pewien czas można by było wymieniać część senatorów. Wskazał również, iż 30 dni na rozpatrzenie ustawy, która przychodzi do Senatu z Sejmu, to zbyt krótki okres na dokonanie w niej przemyślanych zmian. Do podobnego wniosku doszedł były prezes Trybunału Konstytucyjnego prof. Jerzy Stępień, który stanął na stanowisku, iż czas, w którym Senat rozpatruje ustawy, powinien być wydłużony. Do ożywionej dyskusji włączyli się również przybyli goście m.in. dr hab. Wojciech Orłowski z Uniwersytetu Marii Curie-Skłodowskiej w Lublinie.

Krótkie podsumowanie konferencji przeprowadził marszałek Senatu Bogdan Borusewicz. W swojej wypowiedzi podkreślił, że w obecnym czasie jak najbardziej potrzebna jest dyskusja o roli Senatu, a także o zmianach w jego działaniu. Zaznaczył jednak, że jako czynny polityk jest on zwolen- 
nikiem wprowadzania takich zmian, jakie są możliwe w obecnej sytuacji prawnej oraz politycznej.

Na zakończenie tego pracowitego, zimowego dnia Gospodarze Konferencji zorganizowali dla przybyłych gości bankiet.

Korneliusz Łukasik Alicja Brzozowska Uniwersytet Marii Curie-Skłodowskiej w Lublinie 